\title{
It is Fear, Not Disgust, That Enhances Memory: Experimental Study on Students in Bandung
}

\author{
KaYan, Henndy Ginting, and Cakrangadinata \\ Faculty of Psychology \\ Maranatha Christian University
}

\begin{abstract}
A number of research findings have found the impact of emotion on memory. Some researchers stated that disgust has more impact on memory, however according to the current study the effect of fear cannot be ignored. Both disgust and fear are examples of negative emotion that may have a significant influence on behavior, such as in the attempt of creating a healthy lifestyle. The current study involved an experiment where participants were asked to memorize and recall four randomly displayed picture categories that elicit emotions of disgust, fear, joy, and neutral emotion. They also filled out a DS-R (Disgust Scale-Revised) questionnaire and a supporting questionnaire about healthy lifestyle. Analysis of the results showed that disgust did not show an effect on memory, but fear instead did. This is related to the fact that most participants showed a low degree of disgust, and so it was not considered a significant emotion that affected memory compared to fear. In addition, physiologically fear and disgust are managed by different parts of the brain and thus it was assumed that they will have a different impact on memory. The findings implied that, in campaigning for a healthier lifestyle, fear emotion need to be instilled in people.
\end{abstract}

Keywords: disgust, memory, fear, emotion

Sejumlah penelitian yang menemukan bahwa emosi berdampak pada ingatan. Ada yang menyebutkan kemuakan lebih berdampak terhadap memori, namun menurut studi ini dampak ketakutan tak dapat diabaikan. Kemuakan dan ketakutan merupakan contoh emosi yang bersifat negatif dan dapat memiliki dampak yang besar terhadap tingkah laku, seperti dalam membangun perilaku hidup sehat. Penelitian ini dilakukan secara eksperimental dan partisipan diminta menghafal dan mengingat kembali masing-masing empat kelompok gambar yang memberi efek emosi kemuakan, ketakutan, kesenangan, dan netral, yang ditampilkan secara bergantian dan dipilih secara acak. Mereka juga melengkapi kuesioner DS-R (Disgust ScaleRevised) dan kuesioner pendukung yang berkaitan dengan gaya hidup sehat. Pengolahan hasil eksperimen menunjukkan bahwa bukan kemuakan yang menimbulkan efek pada memori, melainkan ketakutan. Hal ini tampaknya berkaitan dengan derajat kemuakan responden yang mayoritas berada dalam kategori rendah, sehingga kemuakan bukanlah emosi yang signifikan tergugah dibanding dengan ketakutan untuk meningkatkan ingatan. Selain itu, secara fisiologis tampaknya ketakutan dan kemuakan dikelola oleh bagian otak yang berbeda, sehingga penulis mengasumsikan akan membuat perbedaan dalam ingatan. Implikasi penelitian ini, demi mengampanyekan pentingnya hidup sehat, maka masyarakat perlu digugah emosinya, dalam arti emosi ketakutannya.

Kata kunci: kemuakan, ingatan, ketakutan, emosi

From an evolutionary perspective, emotion is considered as an adaptation process that helps individuals adjust their physical functions (Nesse \& Ellseworth, as cited in Arch, 2011). In other words, emotion can be a piece of information for someone to protect them-

Correspondence concerning this article should be addressed to Ka Yan, Faculty of Psychology Maranatha Christian University. Jalan Prof. dr. Surya Sumantri No. 65 Bandung 40164, Indonesia. E-mail: kresentia_kayan@yahoo.com selves from environmental hazards. For example, when encountering a large scary dog, fear arises and makes someone run the other direction as a way to protect themselves.

There is a set of processes to assign meaning to information to elicit emotion. According to Schultz et al. (cited in Hascher, 2010), emotion is depicted as ways of being, and a holistic episode involving phy- 
siological, psychological, and behavioral aspects. Emotion is lined with cognition, motivation, and behavior, emotion and be expressed, observed, and physically experienced (Hascher, 2010).

In relations to the cognitive process, emotion is linked with memory. Markman (2013) stated that in the $50^{\text {th }}$ anniversary of the murder of John F. Kennedy, many people were able to provide details of whatever was happening to them during the shooting. This is an astounding event, and many people stated that they have clear memory of the particular day, even after half a century. People who were alive during the Challenger explosion and September 11th also had significant emotional memories of the particular dates. Despite not being $100 \%$ accurate, these showed that people were affected by the emotional experience at the time.

Another emotion of interest is disgust. According to Rozin, Haidt, and McCauley (cited in Olantuji et al., 2007), disgust is seen as a basic response of unclean, contaminated, and potentially diseased stimuli. Disgust consists of three components (Ekman as cited in Rozin, Haidt, \& McCauley, 2008), which are behavioral, physiological, and expressive. Behaviorally, disgust is manifested in keeping a distance from an object, an event, or a situation, and can be characterized as rejection. Disgust is also associated with specific physiological condition which involves nausea and increased salivation. Expressively, it can be seen in someone's facial expression such as pulled upper lip and wrinkled nose.

Furthermore, Haidt (cited in Bitton, 2008), Chapman and Anderson (2012) stated the term "moral disgust", who stated that disgust is not only linked to food or unpleasant images, but also moral issues. Chapman and Anderson gave an example that adults and children who commit moral transgressions (some-thing that is against the laws/norms) are considered disgusting.

Many experiments and clinical studies have used a variety of stimuli (e.g., images, facial expressions, and words) to represent emotion (e.g., Cisler, Bacon, \& Williams, 2009; Yiend, 2010), including disgust (Cisler, Olantuji, Lohr, Williams, 2009). Chapman et al. (cited in Markman, 2013) explained how disgust has an effect on memory. They use a set of pictures that are disgusting, fearful, and neutral. Each image were shown for two seconds. Disgusting pictures showed objects such as cockroaches or terminal illnesses. Fearful pictures depict vicious or wild animal. Neutral ones showed objects such as a coat hanger or a coffee maker.

When the pictures are displayed, a line appears above or below it. Participants need to point at the line as fast as and as accurate as they can. This line is designed to measure the participant's level of attention on the picture. After 10-45 minutes, participants were asked to recall as many pictures as they can (they were not informed to memorize them beforehand). This memory test showed that, in general, people were more likely to recall fearful and disgusting pictures compared to neutral ones. This means that pictures that elicit negative emotion are more memorable. Disgusting pictures were more likely to be recalled than fearful ones. Participants also needed more time to respond on the line with a disgusting picture compared to fearful or neutral. These findings showed that people pay more attention to disgusting pictures, compared to fearful or neutral ones. Another study done by Chapman et al. (cited in Markman, 2013) gave a one week break period between the display of the pictures and the memory test, and the result was just as strong.

There is a number of implications from the research on emotion and memory. Geraerts et al. (cited in Science Daily) stated that individuals will behave according to what they remember. Baumeister et al. (2007) stated that emotion will affect the cognitive process by influencing procedures to behave and make decisions. According to the researcher, when someone recalls a disgusting image, he/she will engage in avoidance behavior to protect him/herself. For example, when recalling that garbage is something that could increase the incidence of disease, one will be more likely to keep clean.

Another negative emotion is fear, and this emotion is comparable to disgust. Both induce a high level of arousal and are usually avoided (Chapman, Anderson, Johannes, Poppenk, \& Moschovitch, 2013. Despite that, Chapman also pointed out a possible difference between disgust and fear. This assumption was based on the uniqueness of disgusting stimuli. In an instant, disgusting materials can contaminate and affect other objects (Rozin \& Fallon, as cited in Chapman et al.). Disgust and contaminated object need to be remembered and to be avoided. Rachman (cited in Chapman et al.,) stated that contaminated objects will stand out from time to time. Therefore, the memory for disgust will persist more. This is in line with Susskind et al (2008) who stated that fear will accelerate eye movement in looking for a target and increase the size of the nasal cavity, which happen in the opposite for disgust. Thus, fear and disgust are linked with a different reaction tendency, and they each activate different areas in the brain (Calder, Lawrence, \& Young, 2001; Murphy, Nimmo-Smith, Lawrence, 2003) so 
the two emotions may give different effects on memory.

Memory is not a simple and linear concept. Other than individual differences in cognitive function, the same individual may possess different memories on the same object in a different situation. Different objects may also give different effects on memory. The authors look at this body of research as something interesting that can have a positive implication on health and the environment. For example, for an anti-smoking campaign, the authors assumed that if the campaign elicits emotional arousal (disgust), then it may encourage people to stop smoking. In addition, no such studies exist in Indonesia, where cultural factors have a role in disgust (Haidt, as cited in Rozin, Haidt, \& McCauley, 1999). For example, what is considered disgusting in Western culture may not have the same impact in Indonesia. As a first step, the authors intended to do the study on a sample of university students who should be more concerned on their health and environment. To that end, the authors look at doing an experiment on the effect of disgust on memory. The authors were also interested in examining gender differences in reactions to disgust (considering the study by Haidt, McCauley, $\&$ Rozin, 1994) who said that women are more sensitive to disgusting stimuli compared to men, and the authors wanted to examine whether students with higher degree of disgust will be more careful with their health in daily activities.

\section{Method}

This study used an experimental method, where the environment is systematically manipulated so that a causal effect on behavior can be observed (Kantowitz, Roediger, \& Elmes, 2008). The design utilized is a repeated measures design, where each individual participates in every condition of the experiment. With this design, the authors do not need to worry about individual differences due participants' own level of control. This design is also called a within subjects design (Graziano \& Raulin, 2010).

\section{Participant Characteristics}

Participants were 130 university students from Universitas Kristen Maranatha, with 68 female (52.3\%) and 62 male (47.7\%) students recruited randomly and voluntarily for the study. Participants were in a good physical condition and not under the influence of chemicals that may affect their memory. Participants wrote alternative times for the research, and they were contacted by the research assistant to ascertain the data collection data.

\section{Measurements and Covariates}

Memory software. This software was constructed by the first author by consulting with a programmer. Initially, there were 50 pictures for each emotion (disgust, fear, joyful/positive, and neutral) collected by the authors. Picture collection was done by considering cultural factors to prevent biases (e.g., curry rice is disgusting for westerners, but not Indonesians). A 1000 megapixel resolution was chosen for each picture for clarity, and they were displayed using a 20 inches monitor. The pictures were tested on 60 students. The students were tasked to rate each picture into four emotions categories with each category ranging from $0-4$, with 0 indicating that the picture absolutely does not represent the emotion and 4 meaning that the picture absolutely represents the emotion. A picture is considered a valid representation of an emotion if participants' average scores on the category differs significantly compared to the average scores on the other categories. Repeated measures ANOVA (Warner, 2008) followed by simple contrast analysis showed valid items, which are 39 items for disgust, 47 items for fear, 35 for joy and 53 for neutral. Three items were added to the neutral category because the authors initially thought that one item for disgust, one item for joy, and one item for fear were seen by participants as neutral. A more specific pool of items was chosen randomly from the valid items, ending up with 35 items for each emotion. Reliability testing were done by calculating the Cronbach's Alpha coefficient, showing high reliability coefficient, with .753 for disgust, .735 for fear, .741 for joy, .752 for neutral.

The Disgust Scale Revised (DS-R). The DS-R (Disgust Scale-Revised) by Haidt et al. (1994) was modified by Olatunji et al. (2007). It contains 27 items, including two distractor items (no. 12 and 16) that should not be scored. The answers range from 0 to 4 , with higher scores indicating higher disgust. This scale enables the authors to distinguish students with high disgust (51-100) to low (0-50). With this scale, the authors should be able to collect data related to the research hypothesis (there is an effect of disgust on memory), which is also linked to the level of disgust of each student.

Results of a Pearson correlation for total items were around $.423-.710$, which means all questions are 
usable, and the scale has a high Cronbach's alpha value of .736, indicating that it is reliable.

\section{Procedure}

Participants will do two stages of research. In the first phase, they were presented with images categorized as disgust, fear, enjoy/positive, and neutral, with 17 images for each category. In the second phase, participants will be given the exact same image categories, but with 18 images per category (resulting in a total of 35 images). In this stage, participants will be asked to answer which image have they seen previously. Following the completion of the experiment, participants were asked to fill out the DS-R scale and a healthy lifestyle questionnaire as supplementary data to provide additional information between disgust and healthy lifestyle, and gender and disgust.

\section{Data Analysis Technique}

To investigate the effect of disgust on memory, scoring was done with the formula: (B-S)/ N x 100\%, where $\mathrm{B}$ is a correct answer, $\mathrm{S}$ is an incorrect answer, and $\mathrm{N}$ is the total number of questions (for each emotional category). Further analysis was done using repeated ANOVA to see the different main effects of each category, with 4 image conditions as a within subjects factor. A contrast test was done to check for differences among the conditions fear, joy, and neutral with disgust.

Linking the data with the DS-R questionnaire results, healthy lifestyle behavior and gender as supporting evidence to see if participants with higher degree of disgust will be more likely to have a healthy lifestyle and whether women have a higher effect of disgust. The authors construct an additional healthy lifestyle questionnaire. The data will then be analyzed with crosstabs and correlation analysis.

\section{Results}

\section{Effect of Disgust on Memory}

With regards to memory, participants scored $M=$ 89.53, $S D=7.63$, for images depicting disgust, $M=$ 95.12, $S D=6.98$, for images depicting fear, $M=$ 90.57, $S D=8.29$, for images depicting joy, and $M=$ $90.04, S D=9.98$ for neutral images. Repeated measure ANOVA showed a significant difference on the memory of participants among the four experimental conditions $F(3,127)=28,96, p<.001$. Contrast analysis showed a significant difference between images depicting disgust and those depicting fear, $F(1,129)=57,46, p<.001$, but there was no significant difference between joy and neutral. The data further suggested a significant memory difference of fear pictures with joy $F(1,129)=29,78, p$ $<.001$, and neutral, $F(1,129)=34,93, p<.001$. These differences are shown in Figure 1.

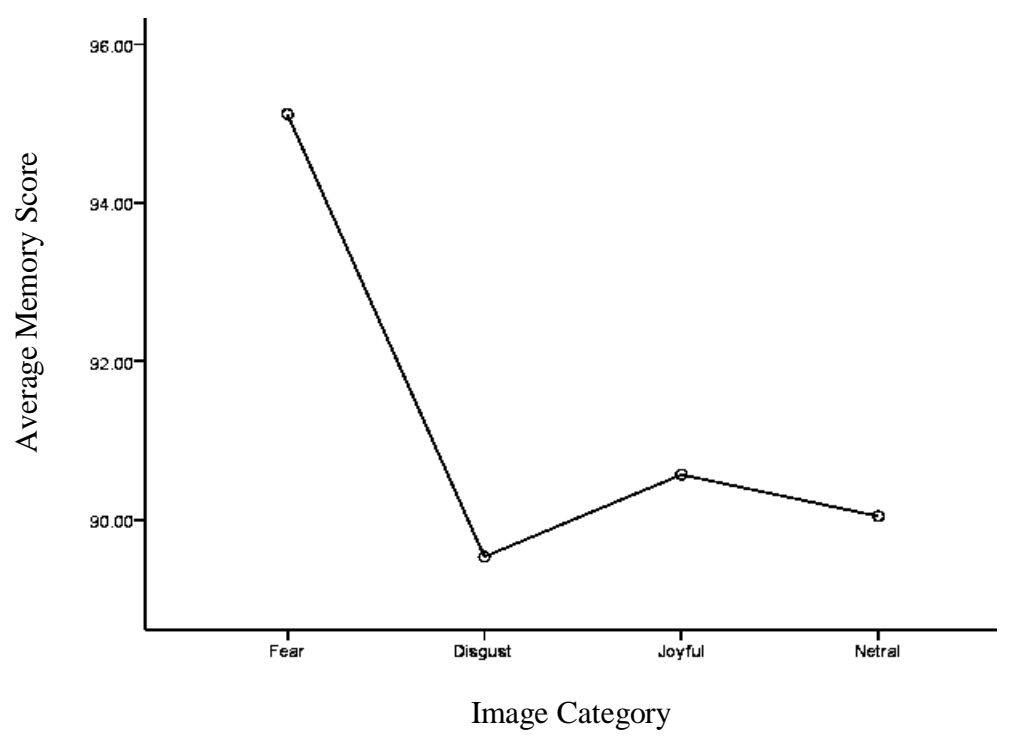

Figure 1. Estimated average difference among memory test scores on different image categories 
From Table 1, it can be seen that disgust requires the most amount of reaction time compared to other emotions. With regards to time, participants had an average score of $M=89.16, S D=29.04$, for disgust, $M=70.68, S D$ $=17.26$, for fear, $M=71.47, S D=16.16$, for joy, dan, $M=67.42, S D=18.91$ for neutral images. Repeated measures ANOVA showed significant differences for participants' reaction time in four experimental conditions, $F(3,127)=28,44, p<.001$. Contrast analysis showed significant reaction time differences between disgust pictures with fear, $F(1,129)=75,13, p<.001$, joy, $F(1,129)=55,86, p<.001$, and neutral, $F(1,129)=$ $76,61, p<.001$. This result showed that participants require longer reaction time on disgusting pictures compared to other pictures. In other words, participants experienced more attentional bias responding to disgusting pictures compared to pictures representing fear, joy, and neutral emotion.

From Table 2, it can be seen that a majority of participants were categorised as having low disgust $(58.5 \%)$ where a majority of male students $(74.2 \%)$ had low disgust level, and female students (55.9\%) had high disgust levels. This is further supported with a correlational test between gender and disgust with a chi square value of $12.08, p=.001(p<.05)$, which means that there is a relationship between gender and disgust on university students.

Table 3 displayed disgust level and two prominent healthy lifestyle behaviors. A total of $74.1 \%$ students with a high disgust level change clothes twice daily, and $81.5 \%$ of high disgust student showered twice daily. However, further correlation analysis between disgust and healthy lifestyle behavior which is changing clothes with a chi square of $=4.299, p=.367(p>.05)$, and showering chi square $=3.827, p=.43(p>.05)$, it can be concluded that there is no significant relationship between level of disgust and healthy lifestyle behavior (changing clothes and showering).

\section{Discussion}

The experiment results of effect of disgust on memory showed that it is not disgust, but fear that showed better memory on students. In other words, students had an easier time recalling fearful pictures compared to disgust, joy, and neutral. This finding is not in line with the hypothesis, and also not in line with the results of Chapman et al. (as cited in Markman, 2013).

Seen from the fact that most students had low level of disgust, it can be interpreted that disgust is not an arousing emotion (despite being a negative emotion),
Table 1

Reaction Time for Four Different Emotions

\begin{tabular}{lc}
\hline \multicolumn{1}{c}{ Emotion } & Average Reaction Time \\
\hline Disgust & $8916 \mathrm{~ms}$ \\
Fear & $7068 \mathrm{~ms}$ \\
Joy & $7147 \mathrm{~ms}$ \\
Neutral & $6742 \mathrm{~ms}$ \\
\hline
\end{tabular}

Table 2

Cross Tabulation Between Gender and Disgust

\begin{tabular}{lccc}
\hline \multirow{2}{*}{ Gender } & \multicolumn{2}{c}{ Level of Disgust } & \multirow{2}{*}{ Total } \\
\cline { 2 - 3 } & Low & High & \\
\hline Male & $46(74.2 \%)$ & $16(25.8 \%)$ & $62(47.7 \%)$ \\
Female & $30(44.1 \%)$ & $38(55.9 \%)$ & $68(52.3 \%)$ \\
Total & $76(58.5 \%)$ & $54(41.5 \%)$ & $130(100 \%)$ \\
\hline
\end{tabular}

Table 3

Cross Tabulation Between Disgust and Healthy

Lifestyle Behavior

\begin{tabular}{lcc}
\hline Level of Disgust & $\begin{array}{c}\text { Change Cloth } \\
\text { 2x/day }\end{array}$ & $\begin{array}{c}\text { Shower } \\
\text { 2x/day }\end{array}$ \\
\hline Low & $50(65.8 \%)$ & $56(73.7 \%)$ \\
High & $40(74.1 \%)$ & $44(81.5 \%)$ \\
Total & $90(100 \%)$ & $100(100 \%)$ \\
\hline
\end{tabular}

so it does not encourage people to remember. Reaction time data of disgust that is longer than other emotions showed that students gave more attention to disgusting stimuli, trying to give meaning to disgusting pictures that is in reality may not arouse any emotions, and this posed as a challenge for them. This is in accord with the results of van Hooff, Devue, Vieweg, and Theeuwes (2013) regarding reaction time for disgust that is significantly longer for fear, and is not more accurate. It was argued that this happened because when participants were presented with disgusting stimuli, participants needed more time and attention to assess whether there were any implicative risks from the picture, and it is difficult for them to do so.

Cognitively, fear elicits a "stop-look-listen" response on sensory acquisition (Gray, as cited in Krusemark \& Wen-Li, 2011) whereas disgust provokes sensory rejection (Rozin \& Fallon, as cited in Krusemark \& Wen-Li, 2011). According to Aldao (2014), despite being negative emotions, both disgust and fear have different targets. An individual will experience fear in a threatening situation. For example, when walking at night and realizing that a big dog is approaching, muscle tension will increase, heart rate will rise, breathing will become faster, and blood pressure will rise. Such physiological changes will be useful to run from the threat or deal with it. In other 
words, these changes will help with the adaptive flight or fight response.

On the other hand, disgust occurs when faced with potential contamination. For example, when encountering a huge amount of waste or being in contact with filthy surfaces. In such situation, heart rate will slow down (Woody \& Techman, as cited in Aldao, 2014), and so will blood pressure and breathing (Eckman et al., as cited in Krusemark \& Wen-Li, 2011). These occur because people do not need fight or flight, but they need to reject potential contaminant (Cisler et al., as cited in Aldao, 2014). In other words, when faced with disgust, someone is not in a threatened or urgent condition.

Another explanation is stated by Calder et al. (2001) who said that fear is located in the amygdala, and this increases a person's visual processing sensitivity. In addition, Krusemark and Wen-Li (2011) stated that disgust and fear evoke different activities in the associative visual area, and this showed different effects in early visual sensory processing and visual attention. The authors assumed that when sensitivity increases, there will be changes in memory as well. This is in line with the study by Haman et al. (as cited in Calder et al., 2001) who stated that memory recognition on positive and negative emotions correlate with the cerebral blood flow region ( $\mathrm{rCBF}$ ) in a specific area in the amygdala, hipocampus and parahipocampal gyrus during encoding. Two areas involved in memory, according to Calder et al., during disgust, located in the insula and basal ganglia. Calder et al. stated that patients who suffered from damages to the amygdala experiences disturbances in acknowledging facial expressions related with fear, whereas abnormality in the insula and basal ganglia areas have an effect on acknowledging facial expression related to disgust. Despite the limited amount of studies, these findings are in accordance to Phillips et al. (cited in Rozin, Haidt, \& McCauley, 2008a) and Husted et al., (cited in Rozin, Haidt, J., \& McCauley, 2008b) who stated that a number of areas in the brain - part of the anterior insula, part of the basal ganglia structures and a number of frontal cortex parts are involved in experiences of disgust. Kim and Jung (2006) also stated that fear is located in the nucleus of the lateral amygdala. This difference in location is assumed to create differences in someone's memory as well.

With regards to joy, it is also located in the amygdala but it lowers the activity of amygdala (Calder et al., 2001). The significance of this study is quite vague, but the authors assume that this is in accordance to Bless and Schwarz (cited in Kensinger, 2007) that negative emotions (in this case fear) can cause errors during memory reconstruction that is less than positive emotion (assumed to be joy). This is consistent with the findings that individuals in negative conditions will process information in a more analytical and detailed manner, whereas those in positive conditions will depend on schemas or thematic information and focuses less on details. In other words, the authors see that when someone experiences joy, they will have lower memory than fear.

From Table 2, it can be seen that gender tends to be correlated with disgust. A majority of female participants were found to have a high degree of disgust, in contrast to men. This data is supported by a significant chi square test, and is in line with past findings by Haidt et al. (1994) who stated that women tend to have higher scores on a disgust scale compared to men.

Based on supporting data on lifestyle (Table 3), it can be seen that even though it seemed that students with high degree of disgust have better care of their hygiene (showering and changing clothes twice daily), correlational test did not show any significant result, and thus students who had a high degree of disgust were not different compared to those with low disgust. Therefore, in general they seem to be displaying their daily hygiene maintenance behavior.

\section{Limitations and Further Studies}

This research did not measure students' physiological processes, and so this can be seen as an assumption that can be researched further. In addition, disgust and fear are usually related with anxiety, such as on those with phobias (Davey, as cited in Rozin et al., 2008a; Berg, 2014) and so future studies can include the variables anxiety and fear.

\section{Conclusion}

In this study, it can be seen that fear affects memory. Thus, it would seem that in campaigning for a healthier lifestyle, people need to experience emotion, specifically fear.

\section{References}

Aldao, A. (2014). How are fear and disgust different? Retrieved from www.thescience ofemotions.htm Arch, N. E. (2011). Effect of disgust on relational memory (unpublished honors thesis). The Florida State University, USA. 
Baumeister, R. F., D.Vohs, K., DeWall, N., \& Zhang, L. (2007). How emotion shape behavior: Feedback, anticipation, and reflection, rather than direct causation. Personality and Social Psychology Review, 11, 167-203. doi: 10.1177/1088868307301033

Berg, H. E. (2014). Emotion regulation of fear and disgust: Implication of anxiety disorders. (unpublished honors thesis). Vanderbilt University, USA.

Bitton, D. (2008). The hierarchy of disgust. Retrieved from www.academia.edu/1031922/Current_Theories _of_Sensory_and_Interpersonal_Disgust

Calder, A. J., Lawrence, A. D., \& Young, A. W. (2001). Neurophysiology of fear and loathing. Nature Reviews Neuroscience, 2, 352-363.

Chapman, H. A., \&. Anderson, A. K. (2012). Understanding disgust. Annals of The New York Academy of Sciences, 1251, 62-76. doi: 10.1111/j.1749-6632.2011.0636 9.x.

Chapman, H. A., Anderson, A. K., Johannes, K., Poppenk, J. L., \& Moschovitch, M. (2013). Evidence for differential of disgust and fear in episodic memory. Journal of Experimental Psychology: General, 142, 1100-1112. doi: 10.1037/a0030503

Cisler, J. M., Bacon A. K., \& Williams, N. L. (2009). Phenomenological characteristics of attentional biases towards threat: A critical review. Cognitive Therapy and Research, 33, 221-234. doi:10.1007/ s10608-007-9161-y

Cisler, J. M., Olantuji B. O., Lohr, J. M., Williams, N. L (2009). Attentional bias differences between fear and disgust: implications for the role of disgust in disgust-related anxiety disorders. Cognition and Emotion, 23, 675-687. doi:10.1080/026999308020 51599

Graziano, A. M., \& Raulin, M. L (2010). Research methods: A process of inquiry. Boston: Pearson Education.

Haidt, J., McCauley, C., \& Rozin, P. (1994). Individual differences in sensitivity to disgust: A scale sampling seven domains of disgust elicitors. Personality and Individual Differences, 16, 701-713.

Hascher, T. (2010). Learning and emotion: Perspective for theory and research. European Educational Research Journal, 9, 13-28. doi:10.2304/eerj.2010.9.1. 13

Kantowitz, B. H., Roediger, H. L. \& Elmes, D. G. (2008). Experimental psychology (9th ed). USA: Wadsworth Thomson Learning

Kensinger, E. A. (2007). Negative emotions enhance memory accuracy: Behavioral and neuroimaging evidence. Association for Psychological Science, 16, 213-218. doi: 10.1111/j.1467-8721.2007.00506.x

Kim, J. J., \& Jung, M. W. (2006). Neural circuits and mechanism involved in Pavlovian fear conditioning: A critical review. Neuroscience and Biobehavioral Reviews, 30, 188-202. doi:10.1016/j.neubiorev.2005. 06.005 .

Krusemark, E. A., \& Wen-Li. (2011). Do all threats work the same way? Divergent effect of fear and disgust on sensory perception and attention. The Journal of Neuroscience, 31, 3429-3434. doi: 10.15 23/JNEUROSCI.4394-10.2011

Markman, A. (2013). How does disgust affect memory? http://www.psychologytoday.com/blog/ulterior-mo tives/201311/how-does-disgust-affect-memory

Murphy, F. C., Nimmo-Smith, I., Lawrence, A. D. (2003). Functional neuroanatomy of emotions: A meta analysis. Cognitive Affective \& Behavioral Neuroscience, 3, 207-33.

Olantuji, B. O., Williams, N. L., Tolin, D. F., Abramowitz, J. S., Sawchuk, C. N., Lohr, J. M., \& Elwood, L. S. (2007). The disgust scale: Item analysis, factor structure, and suggestion for refinement. Psychological Assessment, 19, 281-297. doi: 10. 1037/1 040-3590. 19.3.281

Rozin, P., Haidt, J., \& McCauley, C. R. (1999). Disgust: The body and soul emotion. In T. Dalgleish \& M. J. Power (Eds.), Handbook of cognition and emotion (Chapter 21). John Wiley and Son Ltd. Published Online: 28 JAN 2005. doi: 10.1002/0470013494.ch21

Rozin, P., Haidt, J., \& McCauley, C. R. (2008a). Disgust: The body and soul emotion in the 21st century. In: B. O. Olatunji \& D. McKay (Eds.), Disgust and its disorders (pp. 9-29). Washington, D. C.: American Psychological Association.

Rozin, P., Haidt, J., \& McCauley, C. R. (2008b). Disgust. In M. Lewis, J. M. Haviland-Jones \& L. F. Barrett (Eds.), Handbook of emotions (3rd ed., pp. 757-776). New York: Guilford Press.

Susskind, J. M., Lee, D. H., Cusi, A., Feiman, R., Grabski, W., \& Anderson, A. K. (2008). Expressing fear enhances sensory acquisition. Nature Neuroscience, 11, 843 - 850. doi:10.1038/nn.2138

van Hooff, J. C., Devue, C., Vieweg P. E, \& Theeuwes, J. (2013). Disgust and not fear evoking images hold our attention. Acta Psychologica (Amst), 143, 1-6. doi: 10.1016/ j.actpsy.2013.02.001.

Warner, R. M. (2008). Applied statistics: From bivariate through multivariate techniques. California: Sage Publications, Inc.

Yiend, J. (2010). The effects of emotion on attention: A review of attentional processing of emotional information, Cognition and Emotion, 24, 3-47. doi:10.1080/26999309032056 